\title{
Insulin prevents adoptive cell transfer of diabetes in the autoimmune non-obese diabetic mouse
}

\author{
C.H.Thivolet ${ }^{1}$, E. Goillot ${ }^{2}$, P. Bedossa ${ }^{3}$, A. Durand ${ }^{1}$, M. Bonnard ${ }^{4}$ and J. Orgiazzi ${ }^{1}$ \\ ${ }^{1}$ INSERM U197, ${ }^{2}$ INSERM U80, Lyon, ${ }^{3}$ Hopital Antoine Beclere, Paris and ${ }^{4}$ Centre de Transfusion sanguine, Lyon, France
}

Summary. Early intensive insulin treatment is thought to improve subsequent Beta-cell function in Type 1 (insulin-dependent) diabetic patients. Prophylactic insulin administration also reduced diabetes incidence in diabetes-prone animals. To study the mechanisms by which these effects occur, we tested the ability of insulin therapy in the model of non-obese-diabetic mice, to prevent the penetration of committed T cells into the islets and subsequent Beta-cell destruction. Sublethally irradiated non-obese-diabetic males of 8 weeks of age were adoptively transferred with splenocytes from diabetic donors and treated with the maximum tolerable dosage of fast-acting insulin ( $0.5 \mathrm{U}$, twice daily) until 30 days after cell transfer. Diabetes incidence was compared to control animals injected with the same concentration of insulin diluent. After one month of treatment, the cumulative diabetes frequency was significantly less within the insulintreated group ( 4 of $15,26.6 \%$ ) than in the control group ( 15 of $18,83.3 \% ; p<0.01)$. Pancreatic histological analysis of in- sulin-treated animals revealed a lower severity of insulitis and Beta-cell necrosis and a higher percentage of normal islets $(46.6 \pm 10 \%$ vs $2.3 \pm 2 \%, p<0.01)$, including five $(33 \%)$ mice with no lesions. Immunoperoxydase staining of pancreatic sections indicated similar insulin and ganglioside staining of Beta cells from insulin-treated mice and control animals. Insulin-treated mice had comparable pancreatic insulin content to normal mice. Flow cytometry analysis of spleen cell populations indicated that insulin increased the number of Thy $1,2^{+}$and Lyt-2+ $\mathrm{T}$ cells. Although an effect at the Beta cell level cannot be definitely excluded, several lines of evidence suggest that insulin may influence the capacity of effector $\mathrm{T}$ cells to invade the islets and cause Beta-cell destruction. These effects may have potential interest for future immunointervention trials in Type 1 diabetic patients of recent onset.

Key words: NOD mouse, insulin, diabetes, prevention.
The development of animal models in which diabetes spontaneously occurs [1] as well as prospective studies of first degree relatives where immunological markers are present before the clinical onset of the disease, strongly suggest that Type 1 (insulin-dependent) diabetes mellitus is an autoimmune disease [2]. These observations have encouraged the blocking of the autoimmune Beta-cell destruction in newly-diagnosed patients. On the basis of recent protocols aimed at increasing the number of complete (insulin-free) remissions, it now becomes increasingly evident that optimization of insulin treatment at clinical onset augments the residual Beta-cell mass and increases the number of remissions [3,4]. Several lines of evidence in animal models suggest that antigen expression of Beta cells depends on their functional state $[5,6]$. Prophylactic insulin treatment of Bio/breeding (BB) rats $[7$, 8] and non-obese-diabetic (NOD) mice [9] during the prediabetes phase has been shown to prevent and/or delay the clinical onset of the disease. The precise mechanisms which support these experimental observations are not proven. The present study was designed to examine whether insulin might be effective upon the homing in the pancreas of large amounts of autoreactive T cells transferred into naive syngeneic recipients and therefore prevent Beta-cell destruction and diabetes onset.

\section{Materials and methods}

Mice

NOD mice were bred in our facilities. The incidence of spontaneous diabetes in our colony reached $60 \%$ in females by 25 weeks whereas diabetes occurred in only $20 \%$ of males at the same period. Diagnosis of diabetes was characterized by polydipsia, weight loss, glycosuria and persistent hyperglycaemia were detected by chemstrips (Boehringer Mannheim, FRG). Diabetic NOD females served as donors of autoreactive $T$ cells. Mice were randomized and litter matched for each study. 


\section{Cells}

Splenocytes from diabetic mice were isolated in Hanks' Balanced Salt Solution (HBSS) supplemented with $2 \%$ fetal calf serum (Gibco Laboratories, Grand Island NY, USA). After numeration and viability evaluation, $10^{7}$ cells were $\mathrm{i}$.v. injected into 8 -week-old irradiated NOD males (750 rads), according to the method of Wickers et al. [10] at a time when none of the NOD males had spontaneously developed the disease. In some experiments, spleen cells were first depleted of Beta cells by incubation on petri dishes coated with rabbit anti-mouse Ig (Biosys, Compiègne, France), then transferred at a concentration of $7 \times 10^{6}$ cells.

\section{Protocol of insulin treatment}

Insulin stock solution (Actrapid, Novo-Nordisk, Copenhagen, Denmark) was prepared with a $9 \% \mathrm{NaCl}$ solution at a final concentration of $5 \mathrm{U} / \mathrm{ml}$. Insulin diluent fluid was also obtained from Novo-Nordisk. These stock solutions were changed every three days to prevent insulin degradation. The day following the transfer, mice were injected s.c. twice daily with $0.5 \mathrm{U}$ of insulin (equivalent approximately to $40 \mathrm{U}$ per $\mathrm{kg}$ body weight). Control mice were simultaneously injected with the same amount of insulin diluent. This injection regimen lasted one month. The onset of glycosuria was monitored every two days starting at day 15 . At day 30 , all the mice were killed. Blood glucose levels (BM chemstrips, Boehringer) were monitored $18 \mathrm{~h}$ after the last insulin or diluent injection.

\section{Hormonal evaluation}

Circulating immunoreactive insulin concentrations were determined in experimental mice by a standard radio-immunoassay procedure (Cis International, Gis sur Yvette, France) with rat insulin as standard (Novo-Nordisk). In addition, pancreata from representative animals from both groups as well as normal 8-week-old mice were extracted in $1 \mathrm{ml} 70 \%$ ethanol- $0.18 \mathrm{~N} \mathrm{HCl}$ overnight at $4{ }^{\circ} \mathrm{C}[11]$, and insulin concentrations of the corresponding supernatants were determined.

\section{Detection of insulin antibodies}

Insulin antibodies were determined in the sera of experimental mice by a competitive fluid-phase radiobinding assay as previously documented [12]. Briefly, sera were stripped of insulin with characoal-Dextran prior to incubation for 5 days at $4{ }^{\circ} \mathrm{C}$ with $7500 \mathrm{ng} / \mathrm{ml}$ of Tyr-A14 monoiodinated human insulin (specific activity $270 \mu \mathrm{Ci} / \mu \mathrm{g}$ IRI, NovoBiolabs, Bagsvaerd, Denmark). Immune complexes were separated using cold polyethylene glycol. A competitive displacement with $4000 \mathrm{ng} / \mathrm{ml}$ of serum of unlabelled human insulin (Lilly, Indianapolis, Ind., USA) was performed systematically for each sample to assess specific binding to human insulin.

\section{Histological procedures}

All the mice were killed by cervical dislocation and pancreases were excised immediately and divided into two parts, one for conventional histological studies and the other for immunohistochemical procedures. For the histological studies, samples were fixed in Bouin's alcoholic solution, embedded in paraffin and semi-serial sections were stained with haematoxylin-eosin as described previously [13]. At least 25 islets were examined blind for each sample. Pancreatic islets were scored semi-quan titatively as 0 when islet cells had no visible sign of inflammation, 1 when islets had lymphocytes at the periphery, 3 when islets were completely infiltrated and 4 when islets were atrophied. The percentages of islets of each category were then determined for each pancreas. To detect insulin-secreting cells, sections were stained with an anti-insulin guinea pig serum (Dakopatts, Santa Barbara, Calif., USA) and processed according to the peroxydase-anti-peroxydase procedure. For immunohistochemical studies with anti-ganglioside monoclonal antibodies (mAbs), frozen sections $(4 \mu \mathrm{m})$ were fixed in cold acetone for $10 \mathrm{~min}$, washed in Phosphate Buffered Saline and covered with the specific mAbs at the appropriate dilutions for $1 \mathrm{~h}$.

\section{Monoclonal antibodies}

Rat IgM mAbs used for phenotypical analysis of spleen cell populations by flow cytometry were purified ascites from a panel of clones: clone 30-H12 against Thy-1,2+ cells [14], clone 53-6.7 against Lyt-2+ cells [14], and clone GK 1.5 against $\mathrm{L} 3 \mathrm{~T} 4^{+}$cells [15]. Fluoresceinated mouse mAb specific for rat kappa chain (Mark I, Biosys, Compiègne, France) was used as second reagent. FITC-rabbit antimouse Ig (Dakopatts, Calif., USA) was used for Beta cell analysis. Flow cytometry analysis was performed on a fluorescence-activated cell sorter (FACSCAN, Becton Dickinson, Mountain View, Calif., USA).

Mouse IgM mAbs against islet cell gangliosides were A2B5 and 3G5 (a gift from G.S. Eisenbarth, Joslin Clinic, Boston). Horseradish peroxydase conjugated anti-mouse Ig (Amersham, les Ulis, France) was used as a second reagent.

\section{Statistical analysis}

Cumulative diabetes incidences were compared by the Wilcoxon rank test. Histological scores were compared between insulintreated and control animals using the Mann-Whitney rank test.

\section{Results}

\section{Insulin therapy and transfer of diabetes}

The maximum tolerable insulin dose compatible with survival was determined. A dose of $0.5 \mathrm{U}$ of fast-acting insulin injected s.c. in three mice gave a profound and

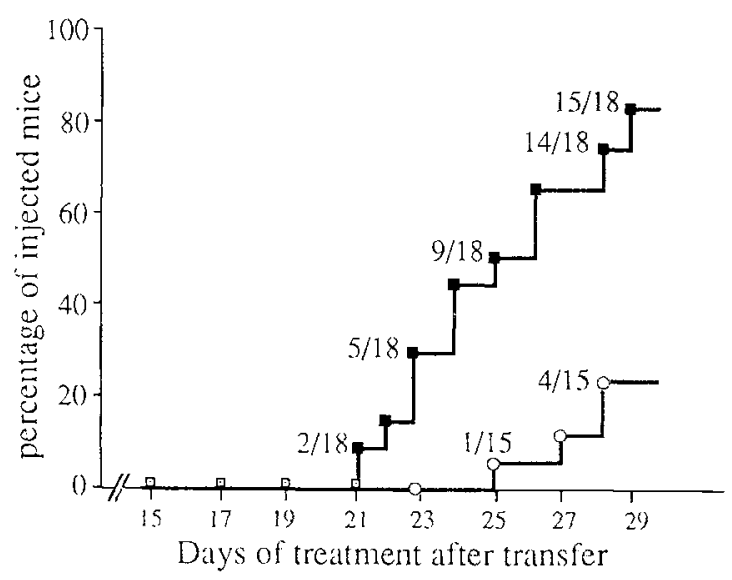

Fig. 1. Cumulative incidence of diabetes observed during two different experiments following adoptive cell transfer. Recipients were either treated with insulin diluent (closed squares) or insulin $0.5 \mathrm{U}$ twice daily (open squares). Non-transferred animals remained nondiabetic during the period of the protocol 
Table 1. Characteristics of insulin-or sham-injected mice, 30 days after transfer of diabetogenic $T$ cells. Mice were killed $18 \mathrm{~h}$ after the last injection

\begin{tabular}{llll}
\hline Mice & $\begin{array}{l}\text { Weight } \\
(\mathrm{g})\end{array}$ & $\begin{array}{l}\text { Blood glucose } \\
\text { levels (mmol/1) }\end{array}$ & $\begin{array}{l}\text { Insulin con- } \\
\text { centration } \\
(\mathrm{mU} / \mathrm{l})\end{array}$ \\
\hline $\begin{array}{l}\text { Diabetic } \\
\text { sham-injected }\end{array}$ & $\begin{array}{l}24.1 \pm 0.8 \\
n=9\end{array}$ & $14.9 \pm 2.2$ & $\begin{array}{l}30.7 \pm 5 \\
n=9\end{array}$ \\
$\begin{array}{l}\text { Non-diabetic } \\
\text { insulin-treated }\end{array}$ & $26.4 \pm 0.8$ & $4.99 \pm 0.25$ & $32.3 \pm 7.5$ \\
$p$ value & $n=9$ & $n=11$ & $n=9$ \\
\hline
\end{tabular}

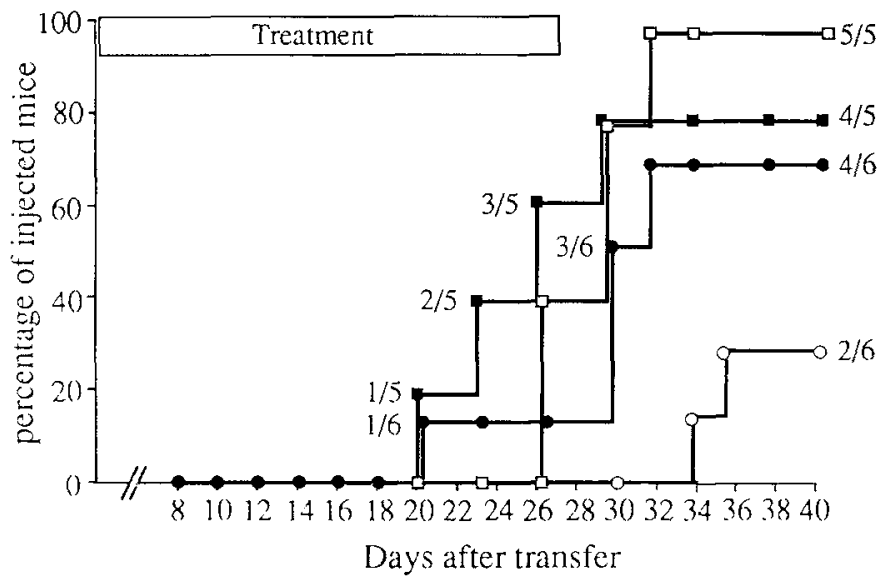

Fig.2. Cumulative incidence of diabetes during different protocols of treatment. Following adoptive cell transfer, mice were either treated twice daily with $0.9 \% \mathrm{NaCl}$ for 28 days (dark squares), with insulin for 15 days then $0.9 \% \mathrm{NaCl}$ for 13 days (open squares), with $0.9 \% \mathrm{NaCl}$ for 15 days then insulin for 13 days (dark circles), and last with insulin for 28 days (open circles)

sustained drop in blood glucose levels from $5.6 \pm 0.5$ to $2.6 \pm 0.4 \mathrm{mmol} / \mathrm{l}, \quad 120 \mathrm{~min}$ after injection $(p=0.002)$. Blood glucose levels return to the normal range at $360 \mathrm{~min}$ but the levels were still significantly different from the control group at $300 \mathrm{~min}(4 \pm 0.3$ vs $5.7 \pm 0.3 \mathrm{mmol} / \mathrm{l}, p=0.0013$ ). No difference was found in body weight and food intake between non-diabetic insulin and sham-injected mice. Thirty days after transfer of $10^{7}$ splenocytes, frequency of diabetes was determined. In order to prevent any remaining effects of insulin therapy on blood glucose levels, all treatments were stopped for $18 \mathrm{~h}$. The cumulative diabetes incidences from two different experiments are shown in Figure 1. The frequency of diabetes in the control group reached $83.3 \%$ $(n=18)$. By contrast, the frequency of diabetes after insulin therapy $(n=15)$ was only $26.6 \%$. This difference was found to be statistically different $(p<0.01)$. The mean \pm SD blood glucose concentration at the end of the study was $18.5 \pm 1.6 \mathrm{mmol} / \mathrm{l}$ for sham-injected mice as compared with $4.75 \pm 0.7 \mathrm{mmol} / 1$ for insulin-treated mice. Diabetic animals had a mean weight loss of $7 \%$ of their initial body weight. Determination of immunoreactive insulin by radioimmunoassay indicated that insulin treatment did not significantly modify the levels of circulating insulin levels in comparison to sham-injected mice (Table 1). No significant difference was found in the level of antibodies to human insulin in both insulin$(0.36 \pm 0.14 \%, \quad n=10)$ or sham-injected animals $(0.15 \pm 0.05, n=9)$. Analysis of hormonal content of pancreatic extracts showed lower insulin levels in diabetic or normal sham-injected mice whereas no significant difference was seen between pancreata from insulin-treated mice and normal control mice. The mean \pm SEM of pancreatic insulin content from five insulin-treated mice did not differ significantly from five normal mice taken as controls (372.8 \pm 41 vs $471.4 \pm 66 \mathrm{mU} / \mathrm{g}$ pancreas, $p=0.3$ ) while pancreata from diabetic mice with destructive insulitis and islet atrophy had low insulin content $(25.9 \pm 11 \mathrm{mU} / \mathrm{g}$ pancreas, $n=3)$.

In order to determine whether protection was linked to a certain period of insulin therapy, the cumulative incidence of diabetes was compared in groups of animals transferred with $7 \times 10^{6} \mathrm{~B}$ cell-depleted splenocytes using different protocols. As shown in Figure 2, while mice treated with insulin for 28 days gave a complete protection, treating mice with insulin for two weeks immediately or at distance from $T$ cell transfer did not protect animals from diabetes.

\section{In situ studies}

The results of histological analysis are shown in Figure 3. Insulin treatment protects the islets from lymphocytic infiltration and Beta-cell necrosis resulting in a higher percentage of intact islets as compared to controls $(46.6 \pm 10 \%$ vs $2.3 \pm 2 \%, p<0.01)$ and a reduced percentage of atrophied islets $(6.6 \pm 6 \%$ vs $47 \pm 12 \%, p<0.01)$ (Fig. $4 \mathrm{a}, \mathrm{b}$ ). Non-diabetic mice under insulin treatment $(n=11)$ did not show signs of atrophy. No difference was found in the percentages of peri-insulitis $(27.8 \pm 6$ vs $18.6 \pm 6)$ or insulitis $(18.8 \pm 7$ vs $32 \pm 9 \%)$. In addition, pancreases from five mice (33\%) which received insulin, were free of insulitis in contrast to none in the control group. Although the degree of infiltrative and destructive lesions was lower in the four mice that became diabetic despite insulin administration, these differences did not

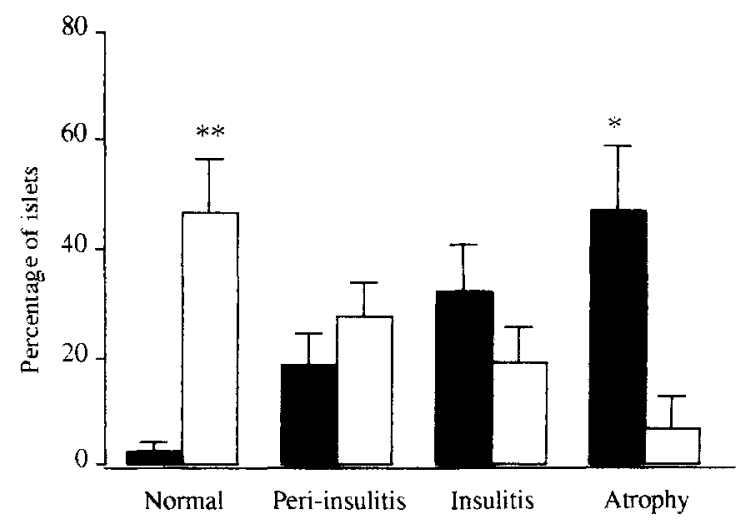

Fig. 3. Severity of insulitis and destructive lesions in diabetic or nondiabetic animals according to $0.9 \% \mathrm{NaCl}$ (dark bars) or insulin (open bars) treatments. The results presented are mean percentages \pm SEM of the results obtained in individual mice during two experiments. An asterisk indicates a level of significance below 0.01 using the Mann-Whitney rank test. 


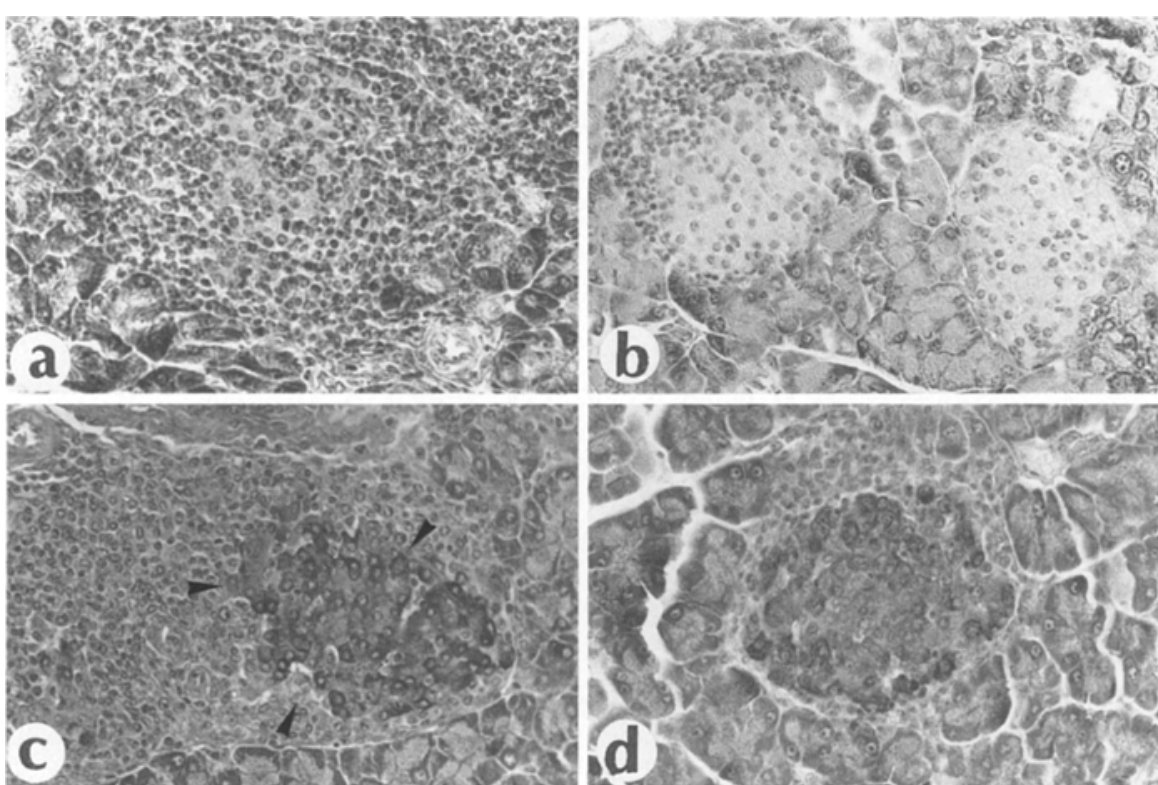

Fig.4a-d. Pancreatic histology from mice transferred with committed T cells and treated with insulin diluent $(\mathbf{a}, \mathbf{c})$ or insulin $(\mathbf{b}, \mathbf{d})$ with a severe insulitis in a sham-injected mouse (a) and one normal islet and one surrounded by a mild insulitis from an insulin-injected mouse (b). Immunoperoxydase staining indicated comparable insulin content in residual Beta cells from control (arrowheads), (c) and insulin-treated animals (d) reach a statistical difference. A significant difference in mean histological scores was noticed between insulin and sham-injected mice $(1.46 \pm 1.2$ vs $3.3 \pm 0.7, p<0.001)$.

Immunoperoxydase staining of pancreatic sections showed no change in the pattern of insulin staining of the Beta cells from both insulin- or sham-injected mice (Fig. 4c, d). Similarly, no difference between groups of experimental mice was noticed in the staining of A2B5 and $3 \mathrm{G} 5$ reactive gangliosides.

\section{Effects of insulin therapy on spleen cell population}

The effects of insulin therapy on $T$ cell subsets were studied in the spleens of seven non-diabetic animals as compared to five normal and two diabetic sham-injected mice. Insulin did not affect significantly the total number of splenocytes in treated animals $\left(103.2 \times 10^{6}\right.$ vs $108.5 \times 10^{6}, p=0.8$ ). However, the phenotypical distribution of cell subsets was modified with a significant increase in the number of Thy $1,2^{+} \mathrm{T}$ cells as indicated in Table 2. Despite the rise in the number of L3T4 ${ }^{+} \mathrm{T}$ cells between the two groups of mice, this difference did not reach statistical significance. On the other hand, the number of Lyt $-2^{-}$T cells was found to be significantly raised $(p<0.05)$.

Table 2. Fluorescein activated cell sorting analysis of spleen cell populations of mice without clinical diabetes, 28 days following T cell transfer. Results are mean $\pm \mathrm{SD}$ of three different experiments

\begin{tabular}{|c|c|c|c|c|}
\hline \multirow[t]{2}{*}{ Mice } & \multicolumn{4}{|c|}{$\%$ positive } \\
\hline & Thy-1,2+ & $\mathrm{L} 3 \mathrm{~T} 4^{+}$ & ${\text {Lyt }-2^{+}}^{+}$ & $\mathrm{Ig}^{+}$ \\
\hline $\begin{array}{l}\text { Sham-treated } \\
n=7\end{array}$ & $32.4 \pm 12$ & $14.8 \pm 10$ & $8 \pm 4$ & $42.8 \pm 10$ \\
\hline $\begin{array}{l}\text { Insulin-treated } \\
n=7\end{array}$ & $45.4 \pm 5$ & $22.6 \pm 9$ & $12.3 \pm 3$ & $54.4 \pm 8$ \\
\hline$p$ value & 0.02 & NS & $<0.05$ & NS \\
\hline
\end{tabular}

\section{Discussion}

Diabetes and Beta-cell necrosis following adoptive transfer of autoreactive $T$ cells can be prevented by prophylactic administration of insulin to the recipients. The NOD mouse, a spontaneous model of human Type 1 diabetes, provides a unique opportunity to investigate the immune mechanisms leading to Beta-cell destruction. The role of $T$ cell mediated immunity is emphasized by the fact that committed $T$ cells from diabetic animals are able to invade the islets of non-diabetic syngeneic recipients and to cause the disease $[10,13]$. This model of adoptive cell transfer in the NOD mouse is important, since both T cell homing in the pancreas and sequential analysis of the destructive lesions can be studied during short observation periods [13]. Godfredson et al. [7] and Like [8] with $\mathrm{BB}$ rats, as well as Atkinson et al. [9] with NOD mice have shown a significant reduction of diabetes incidence by prophylactic insulin treatment. These studies have also underlined that early initiation of treatment and optimal dosage were critical factors in obtaining these beneficial effects. During these protocols, the long period of treatment, exceeding 180 days, is a limitation for the study of the mechanisms involved in these preventive effects. In this study, we indicated that insulin is rapidly effective in blocking large amounts of autoreactive $\mathrm{T}$ cells to cause the disease. In contrast to control mice, no overt islet cell atrophy resulting from prolonged insulin therapy was found. These elements support the concept of a strong immunomodulatory effect of insulin. Although insulin therapy was associated with the conservation of a large number of insulin-producing cells sufficient to prevent hyperglycaemia in the majority of treated mice, infiltration of the islets with mononuclear cells was not completely eradicated. This suggests that insulin-therapy reduced or delayed Beta-cell destruction but did not induce a definitive state of tolerance.

In contrast to previous protocols with insulins containing zinc, a metal-ion known to decrease autoreactive $T$ cell 
function [17], we used here a fast-acting insulin and its solvent as control. Therefore, protective effects of insulin therapy can be ascribed to the insulin molecule itself. The contribution of non-specific variables like the amount of food intake could be excluded since no difference was observed before the occurrence of clinical diabetes. Current hypotheses on insulin-mediated protection are the reduction of antigen expression in Beta cells and/or modulation of effector T cells. The fact that we have demonstrated comparable immunoperoxydase staining of Beta cells for insulin both in insulin- and sham-treated mice. In addition, we have obtained comparable cytoplasmic staining of $\mathrm{A} 2 \mathrm{~B} 5$ and $3 \mathrm{G} 5$ reactive gangliosides in both groups of mice. Altogether, these results do not support the hypothesis that insulin therapy might place the Beta cells at rest, with a lower expression of putative autoantigens. Recent experiments have shown that glucose may induce the expression of several autoantigens, including $\mathrm{IC} 2$ reactive Beta-cell antigen and $\mathrm{A} 2 \mathrm{~B} 5$ reactive ganglioside [5]. Reduction of specific ganglioside expression in islet cells was observed after an insulinoma graft in $\mathrm{BB}$ rats [6]. However, these effects were obtained after long periods of hyperinsulinaemia which do not correspond to the conditions observed in this study. It cannot be excluded however, that low blood glucose levels in insulin-treated mice might influence the rate of Betacell destruction through a reduction of other specific autoantigens not explored in this study.

In fact, our observations reinforce the possibility that insulin might act upon effector T cells. Insulin has growth promoting effects on several tissues, including the thymus. Insulin therapy has been shown to restore the weight and structure of the thymus as well as the number of mature thymocytes of streptozotocin-induced diabetic rats [18]. In the present study, the number of $\mathrm{CD}^{+}$and $\mathrm{CD} 8^{+} \mathrm{T}$ cells increased upon insulin therapy. However, these effects could not be reproduced by treating normal NOD mice with insulin for a period of one week (data not shown). The length of insulin therapy may be critical but the effects of insulin on $T$ cell subsets may also result from the situation of $\mathrm{T}$ cell reconstitution of irradiated animals. Several defects in the T cell response to alloantigens and mitogens have been demonstrated in the NOD mouse [19]. These perturbations were interpreted either as a defect in suppressor cell activation or a decrease in the number of suppressor T cells. Besides growth-promoting effects on lymphoid organs, insulin can act directly on autoreactive $\mathrm{T}$ cells through insulin receptors. For insulin to affect lymphocyte function, the lymphocytes must first become activated in order to express a sufficient number of insulin receptors [20]. It can be postulated that the suppressive effects on the immune response induced by insulin [21] concern mainly activated T cells.

During the recent attempts to prolong Beta-cell survival through the use of immunosuppressive agents [20], insulin requirements were used as a major indicator of success. An immunomodulatory role of insulin should also be taken into consideration for future immunointervention trials in newly-diagnosed diabetic patients. Preservation of Beta-cell function with insulin may also be applied for short and intensive trials in prediabetic individuals with predictive markers for the disease $[12$, 23]

Acknowledgements. This project was supported by INSERM. We thank J. Tourniaire for critical review of the manuscript.

\section{References}

1. Makino S, Kunimoto K, Muraoka Y, Mizushima Y, Katagiri X, Tochino Y (1980) Breeding of a non-obese diabetic strain of mice. Exp Anim 29: 1-13

2. Eisenbarth GS (1986) Insulin-dependent diabetes mellitus: a chronic autoimmune disease. $N$ Engl J Med 314: 1360-1368

3. Mirouze J, Selam JL, Pham TC, Mendoza E, Orsetti A (1978) Sustained insulin induced remissions of juvenile diabetes by means of an external artificial pancreas. Diabetologia 14: 223227

4. Shah SC, Malone JI, Simpson NE (1989) A randomized trial of insulin therapy in newly diagnosed insulin-dependent diabetes mellitus. N Engl J Med 320: 550-554

5. Buschard K, Brogen CH, Röpke C, Rygaard J (1988) Antigen expression of the pancreatic qs is dependent on their functional state as shown by a specific BB rat monoclonal antibody IC2. Acta Pathol Microbiol Immunol Scand 96:342-346

6. Appel MC, Dotta F, O'Neil JJ, Eisenbarth GS (1989) B cell activity regulates the expression of islet antigenic determinants. Diabetologia 32: 461 (Abstract)

7. Godfredson GF, Buschard K, Frandsen EK (1985) Reduction of diabetes incidence of BB Wistar rats by early prophylactic insulin treatment of diabetes prone animals. Diabetologia 28: 933935

8. Like AA (1986) Insulin injections prevent diabetes (DB) in biobreeding/Worcester (BB/Wor) rats. Diabetes 35 [Suppl 1]: 74 (Abstract)

9. Atkinson MA, MacLaren NK, Luchetta R (1990) Insulitis and diabetes in NOD mice reduced by prophylactic insulin therapy. Diabetes 39: 933-937

10. Wicker LS, Miller BJ, Mullen Y (1986) Transfer of autoimmune diabetes mellitus with splenocytes from non-obese diabetic (NOD) mice. Diabetes 35: 855-860

11. Davoren PR (1962) The isolation of insulin from a single cat pancreas. Biochim Biophys Acta 63: 150-153

12. Thivolet $\mathrm{CH}$, Beaufrère $\mathrm{B}$, Betuel $\mathrm{H}$, Geburher $\mathrm{L}$, Chatelein $\mathrm{P}$, Durand A, Tourniaire J, Francois R (1988) Islet cell and insulin autoantibodies in individuals at high risk of development of Type 1 (insulin-dependent) diabetes mellitus: The Lyon family study. Diabetologia 31:741-746

13. Bedossa P, Bendelac A, Bach JF, Carnaud C (1989) Syngeneic $T$ cell transfer of diabetes into NOD newborn mice: in situ studies of the autoimmune steps leading to insulin producing cell destruction. Eur J Immunol 19: 1947-1951

14. Ledbetter JA, Herzenberg LA (1979) Xenogeneic monoclonal antibodies to mouse lymphoid differentiation antigens. Immunol Rev 47:63-71

15. Dialynas DP, Quan ZS, Wall KA, Pierres A, Quintans J, Loken MR, Pierres M, Fitch FW (1983) Characterization of the murine $\mathrm{T}$ cell surface molecule designed L3T4 identified by monoclonal antibody GK 1.5. Similarity of L3T4 to human Leu 3/T4 molecule. J Immunol 131: 2445-2450

16. O'Hare MMT, Shaw C, Swanston-Flatt SK, Marcelli M, Buchanan KD, Flatt PR (1985) Influence of a transplantable insulinoma on the pancreatic status of insulin and pancreatic polypeptide in the rat. Diabetologia 28: 157-160

17. Homsy J, Morrow WJ, Levy JA (1986) Nutrition and autoimmunity: a review. Clin Exp Immunol 65: 473-488

18. Binz K, Joller P, Froesch P, Binz H, Zapf J, Froesch ER (1990) Repopulation of the atrophied thymus in diabetic rats by insulin like growth factor I. Proc Natl Acad Sci USA 87: 3690-3694 
19. Serreze DV, Leiter EH (1988) Defective activation of T suppressor cell function in Nonobese Diabetic mice. J Immunol 140: $3801-3807$

20. Helderman JH (1981) Role of insulin in the intermediary metabolism of the activated thymic derived lymphocyte. J Clin Invest $67: 1636-1642$

21. Hunt U, Eardley DD (1986) Suppressive effects of insulin and insulin like growth factor 1 (IGF-1) on immune responses. J Immunol 136: 3994-3999

22. Feutren G, Papoz L, Assan R, Vialettes B, Karsenty G, Vexiau P, Du Rostu H, Rodier M, Sirmai J, Lallemand A, Bach JF (1986) Cyclosporin increases the rate and the length of remissions in insulin dependent diabetes of recent onset. Lancet II: $119-123$

23. Gorsuch AN, Spencer KM, Lister J, McNally JM, Dean BM, Bottazzo GF, Cudworth AG (1981) Evidence for a long pre- diabetic period in Type 1 (insulin-dependent) diabetes mellitus. Lancet II: $1363-1365$

Received: 10 September 1990

and in revised form: 17 December 1990

Dr. C.H. Thivolet

INSERM U197

Faculté Alexis Carrel

8 rue Guillaume Parradin

F-69008 Lyon

France 